Midstream Value Creation in Social Marketing

Journal of Marketing Management

http://dx.doi.org/10.1080/0267257X.2016.1190777

\title{
Authors:
}

Nadina R Luca (Corresponding author) University of York, Freboys Lane, Heslington,

York YO10 5GD, United Kingdom, +44 7526237165, Email: nadina.luca@ york.ac.uk

\section{Sally Hibbert}

Nottingham University Business School, Jubilee Campus, Wollaton Road, Nottingham NG8 $1 \mathrm{BB}$

\section{Ruth McDonald}

Manchester Business School, Booth Street West, Manchester, M15 6PB, UK 


\title{
Midstream Value Creation in Social Marketing
}

\begin{abstract}
The purpose of this study is to develop improved understanding of how value is created at the midstream (meso) level in a collaborative smokefree homes and cars social marketing programme. The study adopts a qualitative approach including interviews and observation. The findings show that the co-creative organisational model adopted for the Smokefree programme affords access to resources and capabilities of midstream actors and provides opportunities for reshaping and mobilising existing value networks. The focal organisation has a key role in coordinating, connecting actors and providing resources to facilitate value co-creation at the network level. The study illustrates that the service interaction allowed for customer centred cues for action which took into account their context and the existence/lack of resources for value creation. The implications of this study are discussed, in particular in terms of the role of focal organisations in managing value networks, the social context, configurational fit and resources of actors involved in community based social marketing and the need for policies and practices to provide health professionals with role support for health promotion.
\end{abstract}

Keywords: social marketing, community, service perspective, value network, value creation, resources, social context, midstream, smokefree 


\section{Introduction}

Traditional social marketing theory adopted a linear, dyadic view on value creation (Domegan et al., 2013; Luca, Hibbert and McDonald, 2015), focusing on the exchange between two parties (i.e. social marketers and target audience). This perspective has been challenged with recognition of the complexity of factors and actors that influence behaviour and the challenges of defining and creating value in a social change context (Brenkert, 2002; Luca, Hibbert and McDonald, 2015; Peattie and Peattie, 2003). Social change programmes are increasingly seen as complex open systems blending individual and structural factors (Cherrier and Gurrieri, 2014; Domegan et al., 2013). Insight into micro, meso and macro levels, and their reciprocal influence, is needed to understand the system as a whole and inform social marketing programmes that integrate downstream and upstream elements. Yet research into change at the higher levels (meso and macro) of the system, to create social contexts that support behaviour change at the micro level, is scarce. In this paper we focus upon 'midstream social marketing' (Andreasen, 2006), which is concerned with the immediate social environment of target populations, such as community, local institutions (e.g., sports clubs), public services (e.g., education, health services) and personal networks such as family and friends as means to facilitate change (Gordon, 2013; Dibb, 2014; RussellBennett, Wood and Previte, 2013). Community-based models (McKenzie Mohr, 2000) dominate the midstream social marketing literature. They are based on core principles of recognising the value of community assets (in particular knowledge, skills, ideas) (Sharpe et al., 2000; Morgan and Ziglio, 2007) and aim to facilitate ownership of and participation in interventions. This body of research has made valuable contributions to implementation theory by integrating community partnership and social marketing principles to map steps in the process of diagnosing, designing, planning and evaluating community activities (Bryant et al., 2007; Stead, Arnott and Dempsey, 2013). As such, it provides valuable insight into the 
mechanics and activities by which coalitions of community members and organisations collaborate. However, there is relatively little research that addresses why and how questions to explain the processes, dynamics and conditions under which community-based interventions work (McLeroy et al., 2003; Dibb and Carrigan, 2013).

To understand value creation in complex systems it is necessary to unpack the context and processes by which it is shaped. We propose that contemporary marketing scholarship, specifically, service perspectives afford concepts and theory that can help to provide insight into these issues. In this paper we draw upon Service Dominant Logic (SDL), which recognises that value is shaped by social contexts, and views value creation to be a systemsbased process that involves interactions of actors and integration of resources across networks at various levels of an ecosystem (Vargo, 2011; Vargo and Lusch, 2012; 2014; Chandler and Vargo, 2011; McColl-Kennedy et al., 2012). Specifically, we aim to build understanding of the formation and development of midstream social marketing networks and how different actors' experiences of collaboration are shaped by social context.

SDL's key concepts (networks, value co-creation, resources, interactions) are appropriate for the examination of the factors that shape value networks and processes to facilitate or hinder collaboration in a midstream social marketing programme. Our application of SDL's key concepts therefore draws upon network theory that combines analysis of structural and cultural dimensions of networks and connections (Breiger, 2004). The network perspective on value adopted by SDL provides the context for exploring new frameworks and business models to deal with the issues of collaborations at the meso and micro-meso interface in a midstream social marketing programme (Storbacka et al., 2012). The empirical research is carried out in the context of a smokefree homes and cars programme in England. 
The paper starts with a brief introduction of research on midstream social marketing, followed by an overview of service and network concepts central to the theoretical perspective adopted and discussion of the conceptual development that they afford when applied to midstream social marketing. We subsequently outline the context of the current research and the methodological approach adopted and, the findings of the study. The article concludes with a discussion of the main implications of the research for theory and practice.

\section{Midstream Social Marketing}

Social marketing scholars widely advocate a move away from traditional downstream and micro-marketing approaches towards ecological perspectives which account for change at the micro, meso and macro level (Brennan and Binney, 2008; Dibb, 2014; Domegan et al., 2013). Such ecological approaches (Gregson et al., 2001; McLeroy et al., 1988) acknowledge that fostering change within social change open systems requires a system view to understand and tackle the factors that might constrain behaviour at the interpersonal, community, organisational, and societal levels (Brennan and Binney, 2008; Dibb, 2014; Domegan et al., 2013; French, 2011; Gordon, 2013; Hastings, 2003; Luca, Hibbert and McDonald, 2015; Russell-Bennett, Wood and Previte, 2013). Despite this shift in thinking, research that examines how social marketing is applied in practice to address behavioural contexts is still limited (Gordon, 2013; Whitelaw et al., 2010) and scholars continue to call for a broader understanding of processes that strengthen social change programmes (French and BlairStevens, 2010; French, 2011; Gordon, 2013).

The term 'midstream' social marketing was coined to distinguish interventions focused at the community (meso) level, involving collaborations with public services and other community actors (Russell-Bennett, Wood and Previte, 2013) and personal networks such as family and 
friends as means to facilitate change (Gordon, 2013; Dibb, 2014; Russell-Bennett, Wood and Previte, 2013). The types of problems around which these interventions are developed (e.g., environmental sustainability, healthy eating, adolescent drug and alcohol abuse etc.) are not simply a product of personal choice but are shaped by structural factors. Midstream social marketing typically builds upon community-based models, incorporating learning from community development and action research (Bryant et al., 2007; McKenzie-Mohr, 2000; Kelly et al., 2003; Stead, Arnott and Dempsey, 2013). It aims to facilitate collaborative action to address the social, economic, institutional and cultural factors shaping the context of behaviour, although it tends to retain a focus upon psychology theory and marketing management frameworks (i.e., centred on the 'consumer') (Stead, Arnott and Dempsey, 2013).

'Bottom up' approaches are core to community-based interventions (Morgan and Ziglio, 2007; Oakley, 1989), which seek to mobilise and build community capacity to enable participative approaches to identify needs, priorities, resources and solutions. Communitybased social marketing often involves training community members and organisations in social marketing principles to build capacity (Wilkinson, 1989) and enable them to coproduce, strategically plan, design and evaluate community activities (Bryant et al., 2007). However, programmes vary considerably in their adherence to a strictly defined community approach. While some programmes cast a wide net to form a coalition of diverse individuals and organisations that are community stakeholders, others target a subset of midstream actors such as family and peer groups (Carins and Rundle-Thiele, 2014). There is also variety in roles played by different actors (Dibb, 2014; Whitelaw et al., 2010), for instance community members may be involved in problem diagnosis and intervention design and public service professionals or trained researchers take responsibility for evaluation. Evidence suggests that 
active engagement of community actors may help to develop interventions that respond to real needs, are culturally appropriate and generate a sense of ownership and capabilities that have an impact on implementation (Attree, 2004; Johnstone and Campbell-Jones, 2003; Matthews, 2001; Middlestadt et al., 1997; Owens et al., 2011; Waller et al, 2006; Winters and Patel, 2003).

Participative approaches pose considerable management challenges (Domegan et al., 2013) and much of the research into community-based models has focused upon implementation. Particular attention has been devoted to evaluating the readiness of the community (Kelly et al., 2003) and identifying steps in the project management process that enable adherence to the underpinning principles of community collaborations (e.g., participation, empowerment, capacity building) and social marketing (e.g., value exchange, segmentation, formative research, application of marketing, pretesting, monitoring/evaluation), provides vital guidance on what to do and when (Bryant et al., 2007; McKenzie-Mohr, 2000). Existing literature provides some insight into the factors that motivate and inhibit collaboration amongst community actors, but systematic analysis to address question of why and how they work - their dynamics and conditions conducive to success - is sorely needed (Carins and Rundle-Thiele, 2014; Truong, 2014; Whitelaw et al., 2010).

In this study, we respond to calls to build understanding of collaboration of multiple community actors in social marketing interventions (Dibb, 2014; Domegan et al., 2013; Gordon, 2013; Gordon and Gurrieri, 2014; Lefebvre, 2012). Recent scholarship has started to explore such collaborations as a value creation process and has applied service concepts to interrogate the active role of the 'consumer' in social marketing (Russell-Bennet, Previte and Zainuddin, 2009; Zainuddin, Previte and Russell-Bennett, 2011; Zainuddin, Russell-Bennett 
and Previte, 2013; Zainuddin, 2013). Researchers have also applied network and social context theories to conceptualise the processes of multi-actor action, but empirical research, in particular on the socio-cultural dimensions of networks is lacking (Domegan et al., 2013; Luca, Hibbert and McDonald, 2015; Russell-Bennett, Wood and Previte, 2013; Spotswood and Tapp, 2013). We similarly argue that service concepts and theories can inform understanding of collaborations for midstream social marketing. In the following sections we focus specifically on SDL literature on networks, value creation in context, resources and interaction, that is relevant to our key research questions: 'why and how do actors collaborate to create value at the midstream level in social marketing?', 'how does a value network develop at the midstream level?' and 'which factors influence value networks and processes in midstream social marketing?

\section{Value Creation: A network theory informed service view}

Growing support for service perspectives (Grönroos, 2008; 2012; Grönroos and Voima, 2013; Vargo and Lusch, 2004; 2008) marked a shift to a network view on value creation (Storbacka et al., 2012; Vargo and Lusch, 2016). The network perspective on value (Granovetter, 1973; 1985; Gummesson, 2008) provides useful concepts for understanding value creation in a deeper relational context, in particular on the role of individual actors and their connections, social structures and the meaning actors give to these structures (Fuhse and Mützel, 2011). The network view contrasts to the previously dominant 'value chain' perspective on value-in-exchange in marketing which assumes that value is created in the supplier domain and transferred through exchange to customers (Sheth and Uslay, 2007).

Value networks, interaction and reciprocal value propositions 
SDL holds that value creation is an 'emergent process' (Frow et al., 2014; Gummesson, 2008; Vargo and Lusch, 2014) where active customers create value within social contexts comprising networks of various actors (Payne, Storbacka and Frow, 2008) and brings sociology and context oriented theories to the fore, stressing the importance of relationships and interactions among the system's parts. This perspective suggests that value is created not only through dyadic interactions but can be developed over time through interactions within multiple networks of resources or eco-systems (Chandler and Wieland, 2010). Such value networks or service eco-systems are defined as spontaneous spatial and temporal structures which comprise 'social and economic actors interacting through institutions and technology, to: (1) co-produce service offerings, (2) exchange service offerings, and (3) co-create value.' (Lusch, Vargo and Tanniru, 2010, p. 20). The approach adopted by SDL rejects structural determinism (Emirbayer and Goodwin, 1994) acknowledging the changing nature of networks and the role of culture and agency in shaping such networks (Vargo and Lusch, 2016).

The focus on value networks has led to developments in the conceptualisation of value propositions which have evolved from a narrow dyadic focus (typically supplier-customer) to accommodate multiple stakeholders or 'actors' within a service ecosystem (Ballantyne et al., 2011; Frow et al., 2014; Frow and Payne, 2011). The current perspective on value networks implies that an organisation's stakeholders can change roles as initiators of value propositions and participants in the process of value creation and interactions between actors go beyond sale/purchase transactions to include learning, adapting and co-creating (Ballantyne et al., 2011; Vargo and Lusch, 2016). Thus, operating in a 'network of networks' mode (Vargo and Lusch, 2014) allows for reciprocal value propositions, framing various opportunities to cocreate with customers and other stakeholders (Ballantyne et al., 2011). This idea of 
reciprocity illustrates the collaborative nature of value creation and draws upon an actor-toactor perspective (Vargo and Lusch, 2011) that considers all actors to be resource integrators. This view recognises that value is created through economic and social exchange interactions between all actors and institutions including, individuals, families, organisations, communities, cities etc. (Vargo and Lusch, 2012). However, there is often a 'focal actor' who acts as an initiator or planning entity and plays a key role in shaping collaboration within a value co-creation network (Grönroos, 2008; Storbacka et al., 2012). The focal actor in social marketing programmes (i.e. the organiser of social marketing programmes) often needs to engage in outreach work in order to develop connections in the targeted communities and/or identify those actors who can play the role of connectors at the midstream level (Stead, Arnott and Dempsey, 2013). Such efforts require consideration of existing and needed resources for the development of a midstream network but also the fit of the social marketing actions with the actors' contexts.

Interaction processes are central to the creation of networks (Karpen, Bove and Lukas, 2012) as they facilitate the emergence, diffusion and reproduction of meaning amongst actors (Fuhse and Mützel, 2011). Interaction is also seen as central to social marketing efforts to inform, educate, incentivise, influence and support people to change behaviour (Peattie and Peattie, 2003). Through interaction actors engage in dialogue to exchange information but also match, complement and share their resources (e.g. knowledge, skills, relationships etc.) with those of other actors (Gummesson and Mele, 2010). The centrality of dialogue is highlighted by the view that in a changing value network the focal organisation's interaction with the network does not always lead to profit but to feedback and learning (Lusch, Vargo and Tanniru, 2010). Exploring interactions between different actors and the focal actor 
involved in social marketing programmes can shed light on the dynamics of collaboration and the socio-cultural processes involved in negotiating mutual value in social change contexts.

\section{Value -in-context: embedded actors and resources}

SDL views value creation as an embedded process whereby actors interact, directly or indirectly, to facilitate and integrate their own resources and resources from others. Embeddedness is a key concept of the network perspective (Achrol and Kotler, 1999; Granovetter, 1985) adopted by SDL (Vargo and Lusch, 2016). The concept of embeddedness (Granovetter, 1985) suggests that actors are embedded in networks and thus connected and influenced by social ties and norms. The focus on ties and embeddedness suggests the role of trust in guiding actors' willingness to engage with other actors and facilitate collaboration (Granovetter, 1985). Later network theory work points out the need to examine the cultural dimension of networks (e.g. meanings, local practices, social and institutional norms, roles) with an emphasis on the meanings actors give to their contexts (Emirbayer and Goodwin, 1994; Pachucki and Breiger, 2010; White, 2008). From an SD perspective, embeddedness is useful to understand not only relationality in networks (i.e. connections between actors) but also the cultural aspect, in particular how social norms, institutions, social positions, practices and other relationships can be drawn upon as resources in the process of value creation (Archpru Akaka and Chandler, 2011; Vargo and Lusch, 2016).

The cultural dimension of networks is reflected in recent conceptualisations of value in SDL. SDL considers value to be subjectively determined and it was initially captured by the notion of value-in-use reflecting individuals' experiences of an offering. The conceptualisation subsequently evolved to account for contextual factors, incorporating the 'complex dynamic social and economic system comprising networks of actors and institutions' (Archpru Akaka 
and Vargo, 2015, p. 454), and the term value-in-context was adopted. The concept of valuein-context recognises that value creation is influenced by the availability of resources and opportunities for integration, which are shaped by social, institutional and cultural factors (Vargo et al., 2010; Vargo and Lusch, 2016).

The density of resources, available to a specific actor, time, situation and space is considered to contribute to greater value (Storbacka et al., 2012). However, resources need to be understood in context as their status depends upon usage (i.e. their functionality is determined by their use for a specific purpose) (Löbler, 2013); resources are not static but change, evolve and devolve (i.e. when the context diminishes existing resources because of the lack of enabling resources) (Archpru Akaka and Chandler, 2011; Chandler and Vargo, 2011; Vargo and Lusch, 2004). As such, adopting a network view on value creation acknowledges the importance of context, the influence of resource dynamics and individuals' relationships to each other on behaviour in social marketing. The concept of value-in-context accommodates the intangibility of social marketing offerings (Andreasen, 2012) and recognises the processual nature of behaviour which may require accepting value deficits in the short term (e.g. pain, discomfort etc.) in the anticipation of value in the long term (Luca, Hibbert and McDonald, 2015). Further, the view that value is created within a network legitimates a stakeholder orientation and supports the idea of a shift of power from 'social marketers' to other actors (e.g. customers, their peers and family, services etc.).

The network view on value creation brings managerial challenges, in particular associated with the engagement of customers and other actors in co-creation and management of value networks (Ind and Coates, 2013; Storbacka et al., 2012). Little research on co-creation has focused on the processes occurring at the meso level (Domegan et al., 2013; Frow and Payne, 
2011; Storbacka et al., 2012) and how actors 'come together' to form value networks (Chandler and Vargo, 2011). Storbacka and colleagues (2012) propose that frameworks for managing value co-creation need to consider the meso level in order to address the dynamics between actors interacting at different levels and their configurational fit (i.e. fit between their various 'business models' and practices). Development of value networks at the meso level is considered to include a phase of origination (determining which actors participate within a value network, introduction of new resources and capabilities and influences on the practices) followed by processes of mobilisation (communication and learning) and stabilisation of the value network (Storbacka et al., 2012). Despite this emphasis on the meso level, Storbaka and colleagues (2012) recognise that new business models that accommodate value networks should be configured to 'fit' with customer practices (i.e. social marketing change processes). Understanding how value networks originate and develop, but also the processes involved in mobilising and stabilising such networks is key to managing cocreation (Bryant et al., 2007; Stead, Arnott and Dempsey, 2013; Storbacka et al., 2012). Exploring value creation in midstream networks requires understanding the structure in which it is embedded as a dynamic context (Luca, Hibbert and McDonald, 2015). It becomes important to examine not only the existing relationships between various actors but also how common goals, knowledge, social and institutional norms, roles and practices of those actors can act as resources connecting actors within the context and how these networks can create value.

This research contributes to the efforts to further develop midstream social marketing theory (Gordon, 2013) by offering an enhanced understanding of value creation processes and by examining the dynamics and processes unfolding at the meso level. The study contributes to an emerging body of empirical work on value networks, resources dynamics and co-creation 
(Archpru Akaka et al., 2014; Jaakkola and Hakanen, 2013; McColl-Kennedy et al., 2012;

Mele, 2011; Payne, Storbacka and Frow, 2008; Piacentini, Hibbert and Hogg, 2014;

Woodruff and Flint, 2006) and is the first to date to examine the concept of reciprocal value propositions (Ballantyne et al., 2011; Frow et al., 2014; Frow and Payne, 2011) and the sociocultural processes shaping value networks in a social marketing public service context. By doing so, the study contributes understanding of the interactions among organisations, their customers/users, staff and other stakeholders in value networks with implications for community based social marketing models.

\section{The Research Context: The Smokefree Homes and Cars Programme (Smokefree)}

Exposure to second hand smoke represents a major public health risk for both adults (Jamrozik, 2005) and children (Simms et al., 2010; Holliday et al., 2009; Priest et al., 2008). It was estimated to cause 600000 premature deaths per year worldwide in 2004 with $31 \%$ of these occurring among children (Öberg et al., 2011). Smokefree homes initiatives are therefore an important component of tobacco management and control programmes. Despite burgeoning discourse on the need to protect children from second hand smoke at home and a range of media campaigns and both community and individual interventions to encourage parents to create smokefree environments, few studies examine the design and implementation of this type of interventions (Ritchie et al., 2009).

Of the research that has been carried out, promising results have been observed for interaction-based initiatives that feature counselling and advice sessions (Amey, 2011; Priest et al., 2008). Accordingly, a number of smokefree initiatives in the UK have combined social marketing and community-based models to develop a 'pledge' approach to promote the benefits of smokefree homes and cars to target audiences (typically parents) and other 
community stakeholders (Hacker and Wigg, 2010). The pledge approach draws upon sociocognitive models such as the Theory of Planned Behaviour (Amey, 2011; Fishbein and Ajzen, 2010) and aims to address barriers to behaviour change linked to self-efficacy and subjective norms. As such, there is an inherent assumption that individual action and selfmanagement are central to the solution, which has been predominant perspective in health social marketing. However, evaluations of smokefree programmes (Amey, 2011; Hacker and Wigg, 2010; Allmark et al., 2011) point towards collaborative and structural approaches as a means to improve outcomes by involving a range of actors who have the capacity to support the target audiences through a process of behaviour change. Research is needed to understand how and why models and processes of collaboration work.

The case examined in this research emerged from a local public smoking cessation service STOP Smoking that developed a 'Smokefree Homes and Cars programme' (henceforth Smokefree) in 2011 by integrating elements of social marketing with a collaborative community health development approach. The aim of Smokefree is to reduce the prevalence of smoking in homes and cars and to change social norms around in-home/car smoking. The downstream target group was identified as parents of young children living in deprived communities in the city, where the prevalence of smoking is above average and the perceived norm is that 'everybody smokes' (MacAskill et al., 2002). At the midstream level, Smokefree sought the collaboration of local health agencies that have public health goals and, specifically, staff whose roles involve close contact with and/or ongoing relationships with families with young children. These include staff from Children's Centres, Children's Hospital nurses, health visitors, midwives, community health development coordinators [CHDCs] and their volunteers. The purpose of bringing together this network of actors was to harness their capacity to motivate and support behaviour change by having 'conversations' 
with families about Smokefree. Amongst this network, some actors are in a position to have these conversations with a broad range of people who they encounter through their work in the community at places such as Children's Centres, whereas others work more intensively with individual families and are well placed to reach the most at-risk people within the target group, who also tend to face high barriers to behaviour change due to complex combinations of problems in their lives (e.g., domestic violence, drug/alcohol misuse, mental health problems).

This intervention does not strictly adhere to community-based principles in that it was initiated by a team within a public health organisation and has a 'manager' in that organisation. However, formative research was carried out, including both community members and community health workers, to build understanding of the context of the behaviour and develop traditional social marketing elements of the programme including the message (e.g., the potential harm to children of breathing in second hand smoke; the appeal to sign a pledge to keep homes and cars smokefree) and tangible materials (e.g., mug, leaflet, wall chart). The Smokefree intervention is still ongoing and has been able to claim some success. External evaluation commissioned by STOP Services in 2013 included a telephone survey of people who had signed the pledge and the majority of the sample (82\%) reported that they were still adhering to it six months after having signed up (Anonymous Group, 2013).

\section{Research Design}

To address the exploratory questions about collaboration amongst the midstream actors in the Smokefree intervention we adopted a qualitative approach to the research, as advocated by Gummesson (2005) and Fuhse and Mützel (2011). This approach enables exploration and 
description of networks, in particular when they have not been studied as networks before as it was the case for Smokefree (Fuhse and Mützel, 2011). A qualitative approach is appropriate for understanding the processes and the meaning participants give to their context in value networks (Fuhse and Mützel, 2011). A qualitative approach also allows for a conceptualisation of networks as created and modified in social processes acknowledging the role of individuals and agency in shaping these networks (Fuhse and Mützel, 2011; Sewell, 1992).

Data collection involved 47 semi-structured interviews (duration ranged from 30 mins to 2 hours) with community members and staff from health agencies involved in the programme. Interviews were carried out by the lead author and took place at Children's Centres and community libraries or in the participant's home. All interviews were recorded and transcribed verbatim. The study also draws upon 30 hours of observation conducted at five Children's Centres and a children's hospital and 43 informal interviews carried out at the observation sites, following interactions with members of the public and staff on days that observations were carried out. These interviews were not digitally recorded, rather notes were taken during and after the interviews. The sessions observed included group sessions delivered by Children's Centre staff to service users, such as Stay and Play, Peak-a-Boo and Discovering babies. Observation sessions also included the reception activities at Children's Centres, the Smokefree training provided to nurses and the Life Training Support offered to parents in the neonatal section of the Children's Hospital. The field notes were transcribed and coded using the framework designed for interview analysis. In this paper we report the details for only the semi-structured interviews, which are the primary source of evidence for our findings. The study received approval from both the National Health Service (NHS) Research Ethics Committee (REC) and the NHS R\&D departments of the hospital and 
community Trusts where research took place. Ethical guidelines included asking participants for informed consent; informing them about the freedom to withdraw and assuring confidentiality.

We adopted purposive sampling for the semi-structured interviews and aimed to include both members of the public and staff collaborating with Smokefree to gain insight into their experiences as 'end-users' and midstream actors respectively. The size of each group working across parts of the city varied, as did access, which meant it was not possible to conduct a similar number of interview with each type of actor. The 47 participants incorporated 11 members of the public from different areas of the city ( 2 smokers, 3 exsmokers, 6 non-smokers who lived with a smoker), 20 staff working across 9 Children's Centres ( 7 centre leaders/managers, 5 administrator/business support/receptionists, 4 family support officers, 1 children's centre teacher, 3 childcare early learning officers and play workers [CELOS]), 7 health visitors covering 6 areas of the city, 2 Children's Hospital staff, 2 CHDCs covering 3 areas of the city, 2 community midwives and 1 maternity support worker. The interviews included 46 women and one man. This was due to the fact that the vast majority of staff and service users were women. A profile of participants and their pseudonyms is provided in the Appendix. Staff interviewees were identified in collaboration with the Smokefree project manager and the host organisations. In order to avoid potential biases in selecting participants, potential participants were also identified from the researcher's observations at the site or through snowballing techniques (i.e. where participants recommended, other relevant people were identified and invited to participate in the study). Members of the public participants were offered a $£ 10$ voucher as compensation for their participation in the study. 
The data were analysed using a thematic analysis approach guided by answering questions regarding patterns, common themes and deviations from those patterns (Miles and Huberman, 1994). Data were coded and recoded in a systematic and iterative manner to accommodate emerging themes (Miles and Huberman, 1994; Strauss and Corbin, 1994). Pseudonyms are used to report the data in the findings section to protect participant identities and privacy and maintain the anonymity of the programme and research sites.

\section{Findings}

Three key stages of development of the Smokefree value network were evident in our findings, which reveal insight into the social and cultural processes that characterise the origination, mobilisation and stabilisation of the network (Storbacka et al., 2012). This section starts by reporting the configuration of the value network of meso-level actors that was developed for the local Smokefree social marketing campaign to support behaviour change amongst members of the public within the target group. It then presents findings on efforts to mobilise this value network, experiences of implementation and the learning and adaptation processes inherent to stabilising a model that aims to fit with the value and practices of members of the public.

\section{Dynamics of value propositions: origination of the value network}

The network of actors approached to participate in the Smokefree programme was designed to harness the resources of a number of meso-level actors that are part of an existing network of public services in the community who contribute to public health improvement and have specific targets relating to smoking. Smokefree sought to leverage resources afforded by the existing professional/work roles of these actors, their relationships with each other and 
members of the public. Networks formed to enable value co-creation are manifest to customers and other actors through value propositions (Chesbrough and Rossenbloom, 2012) that resonate with the existing cultural content (e.g. roles, practices, norms etc.) (Breiger, 2004; Vargo and Lusch, 2016). To gain the support of midstream actors, then, Smokefree shaped value propositions tailored to actors' roles and responsibilities. The core benefits centre upon health goals aligned with the professional roles of community health workers (such that it is part of 'doing their job') including better health for children, protection of children - specifically, the protection of children from second-hand smoke - cleaner air and a reduction in the number of cigarettes smoked. At an organisational level, Smokefree provides local services with feedback and data reports on their contribution and the number of pledges achieved, which allows them to demonstrate their involvement in tackling smoking for the purpose of service evaluations.

There is a dynamic aspect to the value proposition in that actors change roles as initiators and participants in the Smokefree value network. Initiators and value creation facilitators (other than the focal organisation) also play the role of co-creators and resource integrators at different stages of the interaction with the social marketing offering. The collaborating staff play the role of participants when accepting the value proposition (i.e. Smokefree conversation, training) proposed by the Smokefree team. However, when the staff interact with their users and engage in the Smokefree conversation, they become value proposition initiators. A similar change of role is when service users sign the pledge and engage in conversation about the Smokefree with their own networks.

"It [Smokefree] helped to ... actually it did help to bring up the issue with my... and to reinforce my arguments with my ex-partner of smoking in front of Chris [the child] 
and I think it has ... and I think at the time, she's a lot better now than she was." (Gilbert, member of the public, area $8^{1}$ )

It is notable that collaborating staff sometimes reformulate the value proposition they present to their users (i.e. handing out the leaflet without the 'Smokefree conversation'; using the Smokefree as a tool to support the financial advice they give to their users).

"The way I found it easier to get into it is as soon as they mention debt and you can see a packet of cigarettes on the side. That's been my way in $[\ldots]$ That way you can sort of get in, but it's not an easy subject to approach and people just don't want to know do they? They just say they're stressed. It's just more definitely thinking about how much money you can save is the way they've done it." (Ellie, family support officer, centre 4)

While the community health professionals are motivated to pursue public health goals, their support of Smokefree is partly contingent on the fit with their professional ethos and practices of working with the community. Previous research highlights that collaborative community approaches can raise tensions between the notion of community members as co-creators of interventions and social marketing as an expert-led approach (Spotswood et al., 2012). The manager of Smokefree was conscious of the need to strike a balance, which seemed to make social marketing palatable to community health professionals and this was well received.

"And I think that just shows that that community, yes social marketing alongside the health community's collaborative approach does work." (Minnie, CHDC, area 6)

\footnotetext{
${ }^{1}$ Each Children's Centre is based in a different area of the City. Each area is given a number (i.e. Centre 5 is located in area 5). When the participants are not interviewed/based at the Children's Centre their location is associated with the area number (e.g. area 8)
} 
The ties formed through prior collaborations among local agencies was another factor suggested to be important in bringing together this network of actors for Smokefree. For example, Children's Centre staff (family support officers, childcare teachers and managers) have frequent interactions (direct or indirect) with health visitors and midwives to discuss cases or refer families to one another. STOP and CHDCs, Children's Centres, community midwives and health visitors had previously collaborated to implement smoking cessation projects (e.g. National anti-smoking day, smoking cessation training and STOP clinics). Prior co-operation appears to have created a spirit of shared purpose that motivated the different actors to work together on the Smokefree programme.

“I think for everyone getting involved and helping that way, it's not just the CELOs [childcare education and learning officers], it's the health visitors, it's the nursery nurses, it's everyone, the family support workers, everyone working together to the same aim." (Clarisse, childcare learning officer, centre 4)

\section{Mobilisation of the value network and experiences of implementation: understanding}

\section{embedded actors and resources}

As the focal actor, the Smokefree manager connects and coordinates activities across the network. The key activities in which the midstream actors are asked to engage are to have 'conversations' about Smokefree, to ask members of the public to sign the pledge and to refer people to the STOP service. Smokefree provides resources to facilitate these activities including staff training, pledge forms, Smokefree kits (e.g. information, leaflet, tips and strategies to keep the home and car smokefree) to help health workers to initiate conversations and pledge requests with members of the public and a Smokefree advisor service to which members of the public can be referred to ask questions and receive more information and access to smoking cessation services. 
The Smokefree team provide the staff of collaborating agencies with specialist training on smokefree environments to enable them to incorporate the Smokefree conversation within their normal working practices with members of the public and encourage them to sign the pledge. The training consists of interactive sessions and practice scenarios and it has been conceived as a resource to demonstrate and discuss ways of delivering the message about second hand smoke to the members of the public. The 'brief intervention guide' or 'how to have the conversation' suggested that staff should 'ask' people if they would be interested in learning about Smokefree; 'advise' people about the effects of second hand smoke and 'take action' to ask people to sign up. Participants' accounts suggest that they recognise the value of the training to build knowledge and understanding of the problem of second hand smoke. "...the training was to the point, it was easy, it was knowledgeable and actually it's so needed because you know round here we have so many high numbers of children going to A\&E you know there's such a high proportion of children with asthma and things and glue ear and stuff." (Lucy, practice teacher and health visitor, centres $4 \&$ 8)

It also engages staff with the programme objectives and builds confidence to deliver the message. Conversely, it was noted that staff buy-in and competence to implement Smokefree are reduced when staff miss the training or there are staff changes.

The Smokefree pledge is the primary tool for the programme to achieve a broad reach within the target segments. Children's Centre staff across the city provided the highest number of Smokefree pledges ${ }^{2}$. These actors have organisational roles through which they interact with a large numbers of people and many, especially the receptionists, are willing to extend their

\footnotetext{
${ }^{2}$ Sure Start Children's Centres are a national initiative introduced by the UK Government in 1998 to provide local, integrated and coordinated support services to young children under four and their families (Loyd and Harrington, 2012).
} 
normal responsibilities to contribute to the Smokefree programme. They largely conform to the process advocated by Smokefree, using the free gift to gain interest in the programme and asking people if they are willing to sign the pledge, although they adapt the message as illustrated in the second quote below.

'We're trying to promote that [Smokefree] obviously, everybody that comes in, what we are trying to do is: 'Can you please sign up? [...] so... they fill in this form, and then we give them a free mug, and then we send off the tear off..." (Penny, administrator, Centre 6).

"I mean in some sense each one can be slightly different depending on whether you've got a person that's a non-smoker, a person that's a smoker, couples where one smokes one doesn't and it's quite an interesting, I quite enjoy doing it really." (Sandy, receptionist, centre 8)

They acknowledge that their limited level of interaction, which is incentivised and largely one-way, can lead to outcomes that are superficial or misleading.

"I think it [what motivates people to sign-up] is the free mugs, I know that's awful isn't it but $[. .$.$] Yes, I mean I would hope that [...] a percentage of people will$ genuinely do it for the actual thing of not smoking in the house." (Christy, administrator, centre 4)

In contrast, CHDCs, community midwives and health visitors who work closely with a small number of families have frequent and extensive interactions with them, sometimes over long periods of time. They generally believe that they are in a strong position to engage with the Smokefree message because of the trust they build up. Further, their longer term interactions with clients mean that they can assist them throughout a process of change. These two factors contribute to a density of resources for the social marketing programme that is difficult to achieve without a collaborative model. 
"I think our hit rate on changing behaviour is better, but it's because the contacts we have, especially with the one and under one [year], 'cause it's much more frequent. It's as frequent as the needs of the family and the client are, but also it could be as frequent as that parent decides to bring that child over to us." (Alba, health visitor, centre 12)

In part the trust is a product of their embeddedness and working practices, which they harness for their collaboration in Smokefree. These types of professionals are keen to emphasise that they adopt an approach that is compatible with their normal practice for working with clients, which is person/family-centred, solution-based and involves conversation with clients, acting on their suggestions and being supportive rather than imposing behaviours. For example, family support officers and health visitors raise the issue of parents having to leave children alone in order to go out to smoke. Further, these health professionals integrate the Smokefree proposition into their broader work with the client.

“...it [Smokefree] kind of comes up because we have to do a strengths and needs assessment of the family at the beginning and it's a big long assessment that looks at health, education, family environment all of that stuff so you ask in that do you smoke, do you smoke indoors [...] but you have to [...] assess on an individual basis whether you think you can say to that family 'oh you smoke inside have you ever thought about stepping out we've got this campaign' or whether you need to build that relationship a little bit further first and then address it with them." (Sella, family support officer, centre 2)

Others note that their working practices involve the ability to evaluate whether and when to introduce the idea of a smokefree home such that the client will be receptive.

"When you've first gone in their house [...] how well you think the first half an hour or so has gone and then you know how to approach it. I mean if I went in and the 
mom has started crying and she's really upset, then the paperwork would be the last thing on my mind but the first thing would be to try and get mom or dad obviously sorted and then get them calm and relax before we do anything..." (Kady, family support officer, centre 3)"

"We asked everybody if they're smokers and then you would gauge then whether you felt it was safe to go ahead with this, if somebody glared at you or was stomping up and down then you perhaps wouldn’t do it.” (Lucy, practice teacher and health visitor team manager, centres 4, 6 and 8)

Despite the value of these processes in creating trusting relationships with families, childcare teachers, midwives, health visitors and family support officers all recognise that tension is created by the institutional structures (rules and regulations) that guide their interactions with clients. They highlight the safeguarding aspect of their role in particular as one that introduces a power dimension that limits trust. As Lucy (health visitor team manager, centres 4, 6 and 8) suggested: 'they fear us a little bit'.

"It's having those skills of listening and sitting back, but we sign an agreement with them where we have to say whatever we hear-, if it's obviously child protection we have to take it further, so it's befriending them and getting their trust but on the other hand there's thresholds, you know, we have to make sure the thresholds are not crossed." (Ellie, family support officer, centre 4)

They are conscious that clients sometime feel coerced into listening to their message and complying. In this case, the value of the Smokefree interaction for the members of the public is not related solely to the benefits of the Smokefree offering but is instrumental to maintaining a relationship and avoiding sanctions. 
Although the Smokefree team recognise that staff working in community health can bring resource density to the value network, staff from various collaborating organisations highlight the problem of role overload. The health visitor quoted below notes that she has limited time to spend with families and the Smokefree conversation gets pushed aside when she has more pressing concerns to address during her visits.

"But a lot of [health promotion] is taken away from you 'cause you haven't got the time, 'cause your time is taken up with the families that concern you, that health promotion isn't top of their agenda, it's more about 'can I get rehoused, I'm not getting any money, there's financial problems, domestic violence, and all those types of things take over people's lives." (Shonda, health visitor, centre 11)

Changes at the policy level and budget cuts heightened this problem, generating anxiety amongst staff across agencies participating in the Smokefree programme. For example, the role of health visitors has been extended to include antenatal visits, which means they see more people and, in principle, are able to do more prevention work. One health visitor highlights that there are often discrepancies between the expectations of commissioners and the reality of their work load:

"I think sometimes as well, you feel like those at the top, commissioning you to do these things, don't really understand about the job, see it as straightforward. Where it's unlikely that things are straightforward, 'cause there may be something else that you have to do. And everything takes time." (Marcia, health visitor, centre 10)

Staff also raise the issue that some families are not receptive to the message that, in the extreme, can even lead to safety concerns for health professionals doing home visits. 
“...particularly if you are going into a household where you know that there are concerns regarding child protection and there are far more adults than you in the room with a baby, then you would not, for your own safety, $[. .$.$] you could really be$ opening a can of worms so there are times when you would not, definitely would not be mentioning anything if you could help it. Because sometimes it just is not worth it." (Sandra, health visitor, centre 8)

This highlights the issue that to have the Smokefree conversation is to be responsible for role allocation to the target audience, which can be a tough job when they are not receptive (and sometime vehemently opposed to external interference). Despite support for the programme, some staff in the value network put aside their role in Smokefree if and when it proves to be too difficult and may jeopardise their work and relationship with their users.

The Smokefree team designed an offering (i.e. Smokefree conversation, training and referral report) that was easy to adapt and integrate with partners' practice. Being able to integrate the Smokefree conversation within the everyday practice has facilitated the engagement of staff with the programme. However, this was not enough to motivate everybody to participate. This was particularly the case in the Children's Hospital where very few nurses broach the Smokefree topic. Nurses appear to privilege medical and nursing service over health promotion or health education. Change in the health service has led doctors to pass on some of their responsibilities to nurses and nurses to delegate some of their roles (including health promotion) to the unregistered staff (e.g. community health workers).

“...some staff don't see that is part of their role which is very disappointing because obviously health education is a big part but I think some staff feel, because there's so 
many medical and nursing elements, that they have to deliver that, perhaps health education has its place at a certain time." (Lara, training staff, Children's Hospital)

\section{Stabilising the network through feedback and learning}

The study identified feedback and learning as critical for the central organisation to adapt to the changes of the network, keep partners engaged and facilitate value creation. To connect the resources contributed to returns for actors in the network, the Smokefree team provide feedback on target audience outcomes. Recognition of their efforts and data on the outcomes of partners' involvement is critical to keep partners engaged and to enable timely responses to the changes of the network. Smokefree collaborators acknowledge the responsiveness of the project manager in adapting the programme to their needs.

"I think Kathleen [the Smokefree manager] is really relaxed... I think sometimes it's the worker that's managing the project. She's very open to change, she's open to conversations and she always makes sure you're engaged as well..." (Minnie, CHDC, area 6)

Common health goals, knowledge of their users and institutional norms regarding children's wellbeing play an important role in connecting the actors in the Smokefree network. There is an important collective element to the feedback because community health agencies and their staff have a sense of 'being in this together'. As such, knowing how well partners across the city are doing motivates a collaborative effort.

"Kathleen sending out the figures, city wide, and me sharing them, I think that made the biggest impact on the team." (Victoria, manager, centres $1 \& 2$ ) 
However, organisational structures and Smokefree's limited resources constrain on the frequency and level of feedback to the various actors. For instance, the Smokefree team sometimes rely on managers to share feedback with their teams, which can be hindered by the separation of managers and frontline workers and lack of communication.

"I found out how well we were doing from my Sure Start colleague, 'cause she'd gone into a presentation with Sure Start, and they said, well the health visitors have done this, and we didn't know! So it was like, thank you, okay [...] But it's about me being motivated to go and keep doing it, it's about getting something back for me as a professional, getting something back saying, actually we've done this.” (Alba, health visitor, centre 12)

The most prominent example in this case is that the way the wards are organised in the Children's Hospital does not allow for contact with whole teams of nurses either for training or feedback. The Smokefree team are not able to train the nurses together with the team manager and they are only able to report to the manager (rather than nurses) on staff involvement and the outcomes of the programme.

In the Smokefree context, learning is focused on developing new knowledge for both the social marketing organisation and the collaborator staff. 'Customer learning' is supported by leaflets, promotion and the conversation with service staff, but the manager of Smokefree emphasises, that the programme is not targeted at those individuals who would need strong efforts for capacity building. The staff-social marketing organisation interactions facilitate learning about how each agency works, their operating procedures and practices. Learning is essential not only to build staff capacity (i.e. training) but also for users in building knowledge and developing a sense of competence. 
The approach to developing the value proposition for the Smokefree programme sought to engage members of the community within the target audience - standard social marketing approach. Most interesting here is the interaction with service staff as a means of building shared understanding (rather than using a persuasive message) and development of materials to be used by people in their homes to support a behaviour change process either themselves or in support of another person (e.g., a partner). As such, Smokefree worked with CHDCs and their volunteers in some of the areas with high smoking prevalence to create promotional materials. The manager of the Smokefree project highlighted the importance of interaction with the audience which allowed for feedback and increased understanding of the audience. "But talking to someone in the outpatients at the Children's Hospital waiting with their sick child to go in, that is real feedback on how palatable your message is and if you can sit and talk to them for 5 minutes as opposed to 30 seconds because they don't want to talk to you any more then you've got something that they are interested in listening to. So that level of being open to feedback and listening to what is coming back to you all the time has informed the campaign as we've gone along really." (Kathleen, manager, Smokefree)

Members of the public indicated they preferred the interaction based approach when promoting health information. Participants emphasised that having a conversation with someone about a specific health topic made them more inclined to listen whilst making the message 'real' for them. The experience was also enhanced by the fact that they were receiving the message from someone they trusted. This was also supported by staff who were smokers themselves and found the training had an impact on their smoking behaviour.

"Well, just everything really, what she was saying, although I knew most of it but when it's coming from somebody else it sort of 'Well, yes, that's true' you know? It sort of draws you in more because you've got somebody ... [...] but when somebody 
else explains it, it comes across a hell of a lot better." (Jessica, member of the public, centre 7)

From an organisational perspective, the conversation element allows for constant customer feedback. Talking to people about Smokefree not only provides the opportunity to reach individuals but also to learn more about their own context, smoking habits, the potential barriers to the change and their views and perception of smoking. However, getting people to actually engage and respond to the social marketing proposition requires having a relationship that enables that communication. It also requires genuine interest and a real twoway communication.

“...the way it [Smokefree] was presented, it was quite kind of conversation, chatty informal presentation, which I think always helps. Because you're not being talked to, everyone kind of joins in." (Selena, member of the public, centre 5)

For some of the members of the public and staff (who were smokers) signing the Smokefree pledge was motivated by the desire to change their own behaviour.

“...it helped my husband, obviously he, $[\ldots]$ ignores everything $[\ldots]$...but no, for him to have that information and read it and acknowledge that $[\ldots]$ he's able to see how much he was saving, the money and... and there was this chart as well to see how much he was saving money wise and what it was doing to his health." (Nadira, member of the public, Sal's wife, centre 5)

Interaction with Smokefree also meant altering behaviour in terms of the actions taken by smokers to protect their children from second-hand smoke. Some of the respondents who had partners who smoked indicated that after having been given the information about secondhand smoke, their partners were more cautious not to expose their children to smoke. Actions included washing their hands and mouth after having smoked and going outside to smoke. 
"I suppose with my husband, he's more careful. Like I said, he'll have a shower, wash his face, brush his teeth, all of that. Whereas he might have just thought previously, it's fine. [...] I mean the kids aren't aware that he smokes anyway." (Selena, member of the public, centre 5)

Some of the smokers who signed the pledge recognised that not smoking in the house was seen as an improvement in their behaviour. Furthermore, the action taken to keep the pledge (i.e. going outside to smoke) has helped them reduce the number of cigarettes smoked per day which will have an impact on their health. One step towards changing the habit may work as a barrier or a disincentive to the old behaviour (smoking).

"Yes, because you don't smoke as much because you have to keep going outside because you can't really leave your kids to go outside every few minutes so, yes I've definitely cut down." (Corrine, member of the public, centre 14)

“Definitely because I don’t smoke in my house no more. [...] Only, like I say, the odd time." (Jessica, member of the public, area 7)

Those who signed the pledge and kept their promise not to smoke in the house and car also noticed changes as a result of adopting the behaviour: cleaner air, fresh smell, clean walls. “... and the house is nice now it doesn't smell smoky, our clothes don't smell smoky once they're, you know, washed and things, yes, so that's nice." (Bella, administrator, centre 1)

\section{Discussion and Conclusions}

The research aimed to develop improved understanding of how value is created at the midstream level in social marketing. It adopts an SDL network perspective on value creation 
which recognises both the structural and cultural characteristics of networks (Pachucki and Breiger 2010), and examines how these dimensions shape value propositions, interactions, resources and value-in-context through the development of a smokefree homes and cars social marketing programme. The study highlights the processes of developing, mobilising and stabilising a value network and reveals the experiences at the meso and micro-meso interface. Mobilisation of networks is a main step in community-based approaches but, in the round, the three stages evident in our case study more closely reflect the phases of development for 'network-based business models' in the service literature (Storbaka et al., 2012). As noted above, the value network for the Smokefree intervention was distinct from midstream social marketing that adopts a purer community-based approach in that STOP smoking service was a 'focal organisation' and the Smokefree manager was a 'focal actor' with a mandate to take a leadership role. These additional stages are likely to be common for this type of midstream intervention, with a clear focal actor in a leadership/management role.

The study illustrates a co-creative organisational model wherein actors interact at different levels to integrate their own resources and resources from other actors to create value. The rationale for developing a co-creative organisational model is that it has the potential to augment the density of resources and capabilities and, as such, to facilitate value creation for the actors involved (Storbaka et al., 2012). The model connects this potential with the costs and returns for various actors (Chesbrough and Rosenbloom, 2002). Whereas business models for co-creation generally aim to fit in with customers' practices, social marketing typically seeks to change the practices of target groups. In principle, then, social marketing value networks that have a configurational fit with existing practices as well as transitional processes and understanding of the barriers to change are likely to be better geared to their purpose. The findings show that the organisational model adopted for the Smokefree 
programme affords a configuration of resources (e.g. roles, practices and relationships) from actors within a variety of institutional settings through which it has achieved a broad reach within the target groups in the city as well as deep engagement with the sub-segment of families that face greater health risks.

The study highlights the key role of the Smokefree team (as the focal actor) in mapping and facilitating collaborations at the meso level in order to enable individuals to access resources and develop capabilities required for change. The activities performed by the Smokefree team as the focal actor to build relationships with collaborators and respond to their needs is one example of 'matching' aims, resources and processes for mutual value (Gummesson and Mele, 2010). Integrating the Smokefree message within collaborators' work routine shows potential for avoiding the 'project focus' which tends to dominate health interventions (Whitelaw et al., 2010).

The findings support the emerging literature (Ballantyne et al., 2011; Frow and Payne, 2011; Frow et al., 2014; Kowalkowski et al. (2012) that conceptualises value propositions as cocreated, reciprocal and dynamic within a context influenced by existing resources. The actors' interactions defining the Smokefree value network are shaped by their roles, institutional norms, practices, existing ties and the meanings these actors give to their own realities (Fuhse and Mützel, 2011). While Smokefree as the focal actor has outlined a process and provided training and support, actors within the network who interact with the members of the public contextualise the process and even the goals of the programme to fit with their own working practices and users' realities, for example the idea that staff should promote completely smokefree homes is not always viable (e.g., staff discussed with their clients the solution of smoking in one room to avoid leaving a child unattended). This multi-actor 
dynamic challenges traditional social marketing centred on dyadic exchanges and unidirectional transfer of value (Peattie and Peattie, 2003). The study confirmed previous research which identified the importance of context and highlighted barriers to a smokefree home (Amey, 2011; Jones et al., 2011; Robinson and Kirkaldy, 2007; Robinson and Kirkaldy, 2009). Some of these include the absence of an outside space for smoking, shared accommodation, inability to leave the house due to caring responsibilities, smokefree homes not being seen as a priority, insecurity, and other members of the family that smoked. Despite a certain awareness regarding the negative health effects of second hand smoke (Jones et al. 2011), individual rules around smoking in the house and car are fluid.

The analysis of midstream value creation in the Smokefree case reveals that actors are connected though cognitive (e.g. knowledge, skills, goals) and cultural resources (e.g. norms, roles, practices) in a value network (Breiger, 2004). The density of resources available to the actors participating in Smokefree (e.g. roles, knowledge, relationships, work practices, norms) was identified as a key factor influencing the mobilisation and stabilisation of the value network. However, the programme also highlighted the challenges of operating in a network context and resource deficits (such as time and role support) that diminished the effect of other existing resources (such as relationships and knowledge) and inhibited the process of value creation. In particular, role overload of some staff such as health visitors stresses the need for clear policies regarding health promotion role and resources allocations.

Operating in a network environment brings up questions concerned with accountability, governance and collaboration management (Domegan et al., 2013; Kleindorfer and Wind 2009; Russell-Bennett, Wood and Previte, 2013). The study pointed out the challenges of integrating the capabilities of partners in a value network. Given the public service context of 
Smokefree, the institutional changes driven by government policies, changes to the professions and management have also influenced the value creation network. An important finding of this study highlights that although actors may be connected through partnerships between various public services and common work goals, staff reductions and refocus of the service, constrained the scope and realisation of these collaborations. This highlights the importance of understanding resources and their dynamics as influenced by context (i.e. time, practice, actor) in which institutions play a key role in coordinating value co-creation (Storbacka et al., 2012; Vargo and Lusch, 2016). Although the programme is still on-going, the dynamics of the network caused by policy changes require the Smokefree manager to constantly assess the existing partnerships and seek to engage other partners.

Mobilising and stabilising value networks require processes centred on interaction and dialogue (Ballantyne, 2004; Ballantyne and Varey, 2006; Gummesson and Mele, 2010; Storbacka et al., 2012) to allow for learning, knowledge sharing and resource integration capabilities. Collaborative approaches require process evaluation and constant feedback and interaction between the central organisation and the other collaborators. The study indicates that alongside value propositions, relationships with collaborators and customers are important to facilitate engagement. Identifying and building relationships with key actors who are well embedded in community networks is central for the sustainability of the programme (Bryant et al., 2007). Furthermore, encouraging and facilitating sharing experiences and best practice with the actors involved supports learning, in particular for new staff and innovative strategies to address change.

\section{Implications for future research}


The study extends previous work focused on co-creation (Domegan et al., 2013; RussellBennett, Previte and Zainuddin, 2009) by exploring value creation as a network based process in midstream social marketing. The service perspective that informed this study allowed exploration of network based processes which provide additional insight into the role of social context, configurational fit and resource integration of actors involved in community based social marketing. It contributes an empirical account of how value networks develop and the mobilisation and stabilisation processes involved in open systems such as social change programmes (Gordon and Gurrieri, 2014). The study emphasises the need, acknowledged elsewhere (Dibb and Carrigan, 2013; McLeroy et al., 2003), for developing integrated inter-agency solutions in order to address the fragmented application of social marketing. This study highlights the role of community based services in implementing a social marketing programme and supporting capacity building at the midstream level and stresses that an 'actor-to-actor' stakeholder approach (Chandler and Vargo, 2011) is required to go beyond the consumer to address the social context and target change at different levels.

Funder requirements, short term projects and conflicting stakeholder targets and objectives may limit the time dedicated to relationship building in social marketing (Bryant et al., 2007). Additionally, limited capabilities to capture participant and stakeholder reflexivity understanding of their views and values - (Gordon and Gurierri, 2014) may challenge the reciprocity of value propositions and the development of trust with implications for the stabilisation of value networks. This study supports the recent calls (Brennan and Binney, 2008; Gordon and Gurrieri, 2014) for greater integration of 'stakeholder reflexivity' in social marketing in order to develop sensible and context sensitive programmes. The development of social marketing programmes is shaped by social structural processes that often reflect power imbalances and domination by one group or knowledge form over another (Adams et 
al., 2009). Despite the general discourse that highlighted the importance of building trust relationships and strong ties with the audience, a power dimension has always been present in staff-member of the public relationships due to the institutional rules guiding work practices. The findings suggest that there were situations when interacting with staff regarding Smokefree was not voluntary for service users (e.g. group sessions unrelated to Smokefree where the staff would include Smokefree information). Further, collaborator staff-service user interactions did not always lead to dialogue and there were cases when some staff would simply inform people about Smokefree and ask them to sign up. This might challenge the view that participation in co-creation is always voluntary. However, exposure to Smokefree messages was seen as a step towards increasing awareness and the service users admitted that even when interaction with the staff was limited, they were still able to understand the information received. They were taking the message to their own networks creating value on their own terms. Future research drawing upon customer dominant logic (Heinonen et al., 2010; Heinonen and Strandvik, 2015) and culture and practice theories (Cherrier and Gurrieri, 2014; Spotswood and Tapp, 2013), could contribute additional insight into the consumer's world, which is essential for designing programmes that are sensitive to the needs and realities of the people that are encouraged to change.

The study illustrates that the service interaction allowed for customer centred cues for action which took into account the existence/lack of resources for value creation. However, the study also indicates that in some cases, the members of the public refused to engage with Smokefree. This raises the problem of resistance - a common issue in social marketing programmes. It suggests that actors might not wish to take the role assigned to them by the focal organisation or its collaborators and raises the issue of role allocation in a value network. The role of the focal organisation in creating the context for co-creation and role 
allocation in value networks in social marketing, as well as the resources to support knowledge, skills and motivation building require further attention.

Collaborations around smoking related issues are becoming part of the governance reality (Simms et al., 2010) but is not the case for all health issues and there are concerns about certain partners. Within the Smokefree context, the relationship between the focal organisation and other stakeholders is one of complementarity which is likely to facilitate various forms of cooperation (Zott, Amit and Massa, 2011). However, in other contexts (e.g. environment protection), the relationship between the focal social marketing organisation and stakeholders may be one of competition which requires a different set of activities to facilitate value co-creation. Collaboration between social marketers and for profit, commercial companies remains a challenging area, given the ethical implications in a social marketing context (Hastings as quoted in Dibb and Carrigan, 2013). Such collaborations suggest that maintaining ownership of the social marketing programme and interaction with partners is vital to avoid creating conflicts of interest and diluting the social marketing offering. Further research is needed to investigate value creation processes in other social marketing contexts where the diversity of stakeholders' agendas and the dynamics of the networks pose additional challenges to reaching mutual value propositions. It is also important to investigate the implications of a service and network perspective in social marketing programmes developed in cultural contexts where the integration of services may be lacking.

\section{References}

Achrol, R. \& Kotler, P. (1999). Marketing in the network economy. Journal of Marketing, 63 (2), 146-163. doi:10.2307/1252108 
Adams, J., Hollenberg, D., Lui, C. W. \& Broom, A. (2009). Contextualizing integration: A critical social science approach to integrative health care. Journal of Manipulative and Physiological Therapeutics, 32 (9), 792-798. doi:10.1016/j.jmpt.2009.10.006

Allmark, P., Tod, A. M., McDonnell, A., Al-Alawy, K., Mann, K., Hollis, E., Qutishat, D., Williamson, M. \& Iliff, A. (2011). Evaluation of the impact of a smoke-free home initiative in Rotherham, a deprived district in Northern England. European Journal of Public Health, 1-4, doi:10.1093/eurpub/ckr072

Amey, V. (2011). The design of a smokefree home leaflet and home pack: a Guernsey case study. Health Education, 111 (6), 514-525. doi:10.1108/09654281111180490

Andreasen, A. R. (2012). Rethinking the relationship between social/ nonprofit Marketing and Commercial Marketing. Journal of Public Policy and Marketing, 31 (1), 36-41. doi:10.1509/jppm.09.035

Anonymous Group (2013). Unpublished evaluation report. Phone survey, August 2013, 1-11 (name supressed to comply with the anonymity of the site).

Andreasen, A. R. (2006). Social Marketing in the 21st Century. Sage, Thousand Oaks, CA.

Archpru Akaka, M. and Vargo, S. L. (2015). Extending the context of service: from encounters to ecosystems. Journal of Services Marketing, 29 (6/7). 453-462. doi: 10.1108/JSM-03-2015-0126

Archpru Akaka, M., Corsaro, D., Kelleher, C., Maglio, P. P., Seo, Y, Lusch, R. F. \& Vargo, S. L. (2014). The role of symbols in value cocreation. Marketing Theory, 14 (3), 311-326. doi: $10.1177 / 1470593114534344$ 
Archpru Akaka, M. \& Chandler, J. D. (2011). Roles as resources: A social roles perspective of change in value networks. Marketing Theory, 11 (3), 243-260.

doi:10.1177/1470593111408172

Attree, P. (2004). It was like my little acorn, and it's going to grow into a big tree': a qualitative study of a community support project. Health and Social Care in the Community, 12, 155-161. doi:10.1111/j.0966-0410.2004.00484x

Ballantyne, D., Frow, P., Varey, R. J. \& Payne, A. (2011). Value propositions as communications practice: Taking a wider view. Industrial Marketing Management, 40 (2), 202-210. doi:10.1016/j.indmarman 2010.06.032

Ballantyne, D. \& Varey, R. J. (2006). Creating value-in-use through marketing interaction: the exchange logic of relating, communicating and knowing. Marketing Theory, 6 (3), 335 347. doi: $10.1177 / 1470593106066795$

Ballantyne, D. (2004). Dialogue and its role in the development of relationship specific knowledge. Journal of Business and Industrial Marketing, 19 (2), 114-123. doi:10.1108/08858620410523990

Breiger, R. L. (2004) The analysis of social networks. In: Hardy, M., Bryman, A. (eds.) Handbook of Data Analysis, pp. 505-526. London: Sage.

Brenkert, G. (2002) “Ethical challenges of social marketing”, Journal of Public Policy and Marketing, 21 (1), 14-25. doi:10.1509/jppm.21.1.14.17601

Brennan, L. \& Binney, W. (2008). Concepts in conflict: Social marketing and sustainability. Journal of Nonprofit \& Public Sector Marketing, 20 (2), 261-282.

doi:10.1080/10495140802224951 
Bryant, C. A., Brown, K. R., McDermott, R. J., Forthofer, M. S., Bumpus, E. C., Calkins, S. A. \& Zapata, L. B. (2007). Community-based prevention marketing: organizing a community for health behaviour intervention. Health Promotion Practice, 8 (2), 154-163. doi:10.1177/1524839906290089

Chandler, J. D. \& Vargo, S. L. (2011). Contextualization and value-in-context: How context frames exchange. Marketing Theory, 11 (1), 35-49. doi:10.1177/1470593110393713

Chandler, J. D. \& Wieland, H. (2010). Embedded relationships: Implications for networks, innovation, and ecosystems. Journal of Business Market Management 4, 199-215. doi: $10.1007 / \mathrm{s} 12087-010-0041-5$

Carins, J. \& Rundle-Thiele, S. (2014). Eating for the better: a social marketing review (20002012). Public Health Nutrition, 17 (7), 1628-1639. doi:10.1017/S1368980013001365

Cherrier, H. \& Gurrieri, L. (2014). Framing social marketing as a system of interaction: A neo-institutional approach to alcohol abstinence. Journal of Marketing Management, 30 (78), 607-633. doi:10.1080/0267257X.2013.850110

Chesbrough, H., \& Rosenbloom, R. S. (2002). The role of the business model in capturing value from innovation: Evidence from Xerox corporation's technology spin-off companies. Industrial and Corporate Change, 11 (3), 529-555. doi: 10.1093/icc/11.3.529

Dibb, S. (2014). Up, up and away: social marketing breaks free. Journal of Marketing Management, 30 (11-12), 1159-1185. doi:10.1080/0267257X.2014.943264

Dibb, S. \& Carrigan, M. (2013). Social marketing transformed. Kotler, Polonsky and Hastings reflect on social marketing in a period of social change. European Journal of Marketing, 47 (9), 1376-1398. doi:10.1108/EJM-05-2013-0248 
Domegan, C., Collins, K., Stead, Martine, McHugh, P. \& Hughes, T. (2013). Value cocreation in social marketing: Functional or fanciful?. Journal of Social Marketing, 3 (3), 239256. doi: 10.1108/JSOCM-03-2013-0020

Emirbayer, M. \& Goodwin, J. (1994). Network analysis, culture and the problem of agency. American Journal of Sociology, 99 (6), 1411-1454. doi:10.1086/230450

Fishbein, M., \& Ajzen, I. (2010). Predicting and changing behavior: The Reasoned Action Approach. New York: Taylor \& Francis.

French, J. (2011). Why nudging is not enough. Journal of Social Marketing, 1 (2), 154-162. doi: $10.1108 / 20426761111141896$

French, J. \& Blair-Stevens, C. (2010). Improving lives together. London: Westminster City Council.

Frow, P., McColl-Kennedy, J. R., Hilton, T., Davidson, A., Payne, A. \& Brozovic, D. (2014). Value propositions: A service ecosystems perspective. Marketing Theory, 14 (3), 327-351. doi: $10.1177 / 1470593114534346$

Frow, P. \& Payne, A. (2011). A stakeholder perspective of the value proposition concept. European Journal of Marketing 5 (1/2), 233-240. doi:10.1108/03090561111095676

Fuhse, J. \& Mützel, S. (2011). Tackling connections, structure, and meaning in networks: Quantitative and qualitative methods in sociological network research. Quality and Quantity, 45 (5), 1067-1089. doi:10.1007/s11135-011-9492-3

Gordon, R. \& Gurrieri, L. (2014). Towards a reflexive turn: social marketing assemblages. Journal of Social Marketing, 4 (3), 261-278. doi: 10.1108/JSOCM-02-2014-0015 
Gordon, R. (2013). Unlocking the potential of upstream social marketing. European Journal of Marketing, 47 (9), 1525-1547. doi: 10.1108/EJM-09-2011-0523

Granovetter, M. S. (1985). Economic action and social structure: the problem of embeddedness. American Journal of Sociology, 91 (3), 481-510. doi:10.1086/228311

Granovetter, M. S. (1973). The strength of weak ties. American Journal of Sociology, 78 (6), 3-30. doi:10.1086/225469

Gregson, J., Foerster, S.B., Orr, R., Jones, L., Benedict, J., Clarke, B., Hersey, J., Lewis, J. \& Zotz, K. (2001). System, environmental, and policy changes: using the Social-Ecological Model as a framework for evaluating nutrition education and Social Marketing programs with low-income audiences. Journal of Nutrition Education, 33 (Supplement 1), S4-S15. doi:10.1016/S1499-4046(06)60065-1

Grönroos, C. and Voima, P. (2013). Critical service logic: making sense of value creation and co-creation. Journal of the Academy of Marketing Science, 41 (2), 133-150. 10.1007/s11747012-0308-3

Grönroos, C. (2012). Conceptualising value co-creation: A Journey to the 1970s and back to the future. Journal of Marketing Management, 28 (13-14), 1520-1534. doi: $10.1080 / 0267257 X .2012 .737357$

Grönroos, C. (2008) Service logic revisited: who creates value? And who co creates?. European Business Review, 20 (4), 298-314. doi: 10.1108/09555340810886585 
Gummesson, E. \& Mele, C. (2010). Marketing as value co-creation through network interaction and resource integration. Journal of Business Market Management, 4, 181-198. doi:10.1007/s12087-010-0044-2

Gummesson, E. (2008). Customer centricity: reality or a wild goose chase?. European Business Review, 20 (4), 315-330. doi:10.1108/09555340810886594

Gummesson, E. (2005). Qualitative research in marketing. Road-map for a wilderness of complexity and unpredictability. European Journal of Marketing, 39 (3/4), 309-327. doi: $10.1108 / 03090560510581791$

Hacker, J. \& Wigg, E. (2010). Evaluation of a three-stage, community smoke-free homes project. Health Education, 110 (3), 186-196. doi:10.1108/09654281011038859

Hastings, G. (2003). Relational paradigms in social marketing. Journal of Macromarketing, 23 (1), 6-15. doi:10.1177/0276146703023001006

Heinonen, K. \& Strandvik, T. (2015) Customer-dominant logic: foundations and implications. Journal of Services Marketing, 29 (6/7), 472-484. doi: 10.1108/JSM-02-20150096

Heinonen, K., Strandvik, T., Mickelsson, K. J., Edvardsson, B., Sundström, E. \& Andersson, P. (2010). A customer-dominant logic of service. Journal of Service Management, 21 (4), 531-548. doi: 10.1108/09564231011066088

Holliday, J. C., Moore, G. F. \& Moore, L. A. R. (2009). Changes in child exposure to secondhand smoke after implementation of smoke-free legislation in Wales: a repeated crosssectional study. BMC Public Health, 9, 430. doi:10.1186/1471-2458-9-430 
Ind, N. \& Coates, N. (2013), The meanings of co-creation. European Business Review, 25 (1), 86-95. doi: 10.1108/09555341311287754

Jaakkola, E. \& Hakanen, T. (2013). Value co-creation in solution networks. Industrial Marketing Management, 42, 47-58. doi:10.1016/j.indmarman.2012.11.005

Jamrozik, K. (2005). Estimate of deaths attributable to passive smoking among UK adults: database analysis. British Medical Journal, 330 (7495), 812-824. doi:

10.1136/bmj.38370.496632.8F

Johnstone, D. \& Campbell-Jones, C. (2003). Skills for regeneration: Learning by Community Champions. Educe and the Department for Education and Skills, London.

Jones, L., Atkinson, O., Longman, J., Coleman, T., McNeil, A. \& Lewis S. A. (2011). The motivators and barriers to a smokefree home among disadvantaged caregivers: identifying the positive levers for change. Nicotine Tobacco Research, 13 (6), 479-486.

doi:10.1093/ntr/ntr030

Karpen, I. O., Bove, L. L. \& Lukas, B. A. (2012). Linking Service-Dominant Logic and strategic business practice: A conceptual model of a Service-Dominant Orientation. Journal of Service Research, 15 (1), 21-38. doi:10.1177/1094670511425697

Kelly, K. J., Edwards, R. W., Comello, M. L. G., Plested, B. A., Jumper Thurman, P. \& Slater, M. D. (2003). The Community Readiness Model: a complementary approach to social marketing. Marketing Theory, 3 (4), 411-426. doi:10.1177/1470593103042006

Kleindorfer, P. \& Wind, Y. (2009). The Network Imperative: Community or Contagion? in Kleindorfer, P. \& Wind, Y. (eds), The Network Challenge Strategy, Profit, and Risk in an Interlinked World, Pearson Education Inc, New Jersey, pp. 3-23. 
Kowalkowski, C., Persson Ridell, O., Röndell, J. G. \& Sörhammar, D. (2012). The cocreative practice of forming a value proposition. Journal of Marketing Management, 28 (1314), 1553-1570. doi:10.1080/0267257X.2012.736875

Lefebvre, C. R. (2012). Transformative social marketing: Co-creating the social marketing discipline and brand. Journal of Social Marketing, 2 (2), 118-129. doi:

$10.1108 / 20426761211243955$

Lloyd, N. \& Harrington, L. (2012). The challenges to effective outcome evaluation of a national, multi-agency initiative: The experience of Sure Start. Evaluation, 18 (1), 93-109. doi:10.1177/1356389011429631

Löbler, H. (2013) "Service-Dominant Networks: An evolution from the Service-Dominant Logic perspective", Journal of Service Management 24 (4), 420-434. doi: 10.1108/JOSM-012013-0019

Luca, N. R., Hibbert, S. \& McDonald, R. (2015). Towards a service-dominant approach to social marketing. Marketing Theory, (published online first). doi: $10.1177 / 1470593115607941$

Lusch, R.F., Vargo, S.L. \& Tanniru, M. (2010). Service, value networks and learning. Journal of the Academy of Marketing Science, 38 (1), 19-31. doi:10.1007/s11747-008-0131-z Matthews, H. (2001). Citizenship, youth councils and young people's participation. Journal of Youth Studies, 4, 299-318. doi:10.1080/13676260120075464

MacAskill, S. Stead, M., MacKintosh, A. M. \& Hastings, G. (2002) "You cannae just take cigarettes away from somebody and no' gie them something back": Can social marketing help 
solve the problem of low-income smoking?", Social Marketing Quarterly, 8 (1), 19-34. doi: $10.1080 / 15245000212538$

McColl-Kennedy, J. R., Vargo, S. L., Dagger, T. S., Sweeney, J. C. \& Van Kasteren, Y. (2012). Health care customer value cocreation practice styles. Journal of Service Research, 15 (4), 370-389. doi:10.1177/1094670512442806

McKenzie-Mohr, D. (2000). Promoting sustainable behaviour: An introduction to community-based social marketing. Journal of Social Issues, 56 (3), 543-554. doi: $10.1111 / 0022-4537.00183$

McLeroy, K. R., Norton, B. L., Kegler, M. C., Burdine, J. N. \& Sumaya, C. V. (2003). Community-Based Interventions. American Journal of Public Health, 93 (4), 529-533. doi: 10.2105/AJPH.93.4.529

McLeroy, K. R, Bibeau, D., Steckler, A. \& Glanz, K. A. (1988). An ecological perspective on health promotion programs. Health Education Quarterly, 15, 351-377. doi:

$10.1177 / 109019818801500401$

Mele, C. (2011). Conflicts and value co-creation in project networks, Industrial Marketing Management, 40, 1377-1385. doi:10.1016/j.indmarman.2011.06.033

Middlestadt, S. E., Schechter, C., Peyton, J. \& Tjugum, B. (1997). Community involvement in health planning: Lessons learned from practicing social marketing in a context of community control, participation and ownership, in M. E. Goldberg, M. Fishbein \& S. E. Middlestadt, (Eds.), Social marketing Theoretical and practical perspectives, Mahwah, NJ: Erlbaum, pp. 291-311. 
Miles, M. B. \& Huberman, A. M. (1994). Qualitative data analysis (2 $2^{\text {nd }}$ ed.) Thousand Oaks, CA: Sage.

Morgan, A. \& Ziglio, E. (2007). Revitalising the evidence base for public health: an assets model. Promotion \& Education, 14, 17-22. doi:10.1177/10253823070140020701x

Oakley, P. (1989) Community involvement in health development: An examination of critical issues, Geneva: World Health Organisation.

Owens, C., Farrand, P., Darvill, R., Emmens, T., Hewis, E. \& Aitken, P. (2011). Involving service users in intervention design: a participatory approach to developing a text messaging intervention to reduce repetition of self-harm. Health Expectations, 14, 285-295. doi:10.1111/j.1369-7625.2010.00623.x

Öberg, M., Jaakkola, M. S., Woodward, A., Peruga, A. \& Prüss-Ustün, A. (2011). Worldwide burden of disease from exposure to second-hand smoke: a retrospective analysis of data from 192 countries. The Lancet, 377, 139-146. doi:10.1016/S0140-6736(10)61388-8

Pachucki, M. A. \& Breiger, R. L. (2010). Cultural holes: beyond relationality in social networks and culture. Annual Review Sociology 36, 205-224.

doi:10.1146/annurev.soc.012809.102615

Payne, A. F., Storbacka, K. \& Frow, P. (2008). Managing the co-creation of value. Journal of the Academy of Marketing Science, 36, 83-96. doi:10.1007/s11747-007-0070-0

Peattie, S. \& Peattie, K. (2003). Ready to fly solo? Reducing social marketing's dependence on commercial marketing theory. Marketing Theory, 3 (3), 365-385.

doi:10.1177/147059310333006 
Piacentini, M., Hibbert, S. \& Hogg, M. (2014). Consumer resource integration amongst vulnerable consumers: care leavers in transition to independent living. Journal of Marketing Management, 30 (1), 201-219. doi:10.1080/0267257X.2013.800897

Priest, N., Roseby, R., Waters, E., Polnay, A., Campbell, R., Spencer, N., Webster, P. \& Ferguson-Thorne, G. (2008). Family and carer smoking control programmes for reducing children's exposure to environmental tobacco smoke. Cochrane Database of Systematic Reviews, 4: CD001746. doi: 10.1002/14651858.CD001746.pub2

Ritchie, D., Amos, A., Phillips, R., Cunningham, S., Martin, B. \& Martin, C. (2009). Action to achieve smoke-free homes- an exploration of experts' views. BMC Public Health, 9, 112. doi:10.1186/1471-2458-9-112

Robinson, J. \& Kirkcaldy, A. J. (2009). Imagine all that smoke in their lungs': parents' perceptions of young children's tolerance of tobacco smoke. Health Education Research, 24, 11-21. doi:10.1093/her/cym080

Robinson, J. \& Kirkcaldy, A. J. (2007). You think that I'm smoking and they're not': why mothers still smoke in the home. Social Science and Medicine, 65, 641-652. doi:10.1016/j.socscimed.2007.03.048

Russell-Bennett, R., Wood, M. \& Previte, J. (2013). Fresh ideas: Services thinking for social marketing. Journal of Social Marketing, 3 (3), 223-238. doi:10.1108/JSOCM-02-2013-0017

Russell-Bennett, R., Previte, J. \& Zainuddin, N. (2009). Conceptualizing value creation for social change management. Australasian Journal of Marketing, 17, 211-218. doi:10.1016/j.ausmj.2009.06.002 
Sewell, W. H. Jr. (1992). A theory of structure: Duality, agency, and transformation. American Journal of Sociology, 98 (1), 1-29. doi:10.1086/229967

Sharpe, P. A., Greaney, M. L., Lee, P. R. \& Royce, S. W. (2000). Assets-oriented community assessment. Public Health Reports, 115 (2/3), 205-211.

Sheth, J. N. \& Uslay, C. (2007). Implications of the revised definition of marketing: From exchange to value creation, Journal of Public Policy and Marketing, 26 (2), 302-307. doi: 10.1509/jppm.26.2.302

Simms M., Tomkins S., Judge K., Taylor G., Jarvis M. J. \& Gilmore A. (2010). Trends in and predictors of second hand smoke exposure indexed by cotinine in children in England from 1996-2006. Addiction, 105 (3), 543-553. doi:10.1111/j.1360-0443.2009.02805.x

Spotswood, F. \& Tapp, A. (2013). Beyond persuasion: A cultural perspective of behaviour. Journal of Social Marketing 3 (3), 275-294. doi: http://dx.doi.org/10.1108/JSOCM-01-2013$\underline{0006}$

Spotswood, F., French, J., Tapp, A. \& Stead, M. (2012). Some reasonable but uncomfortable questions about social marketing. Journal of Social Marketing, 2 (3), 163-175. doi: $10.1108 / 20426761211265168$

Stead, M., Arnott, L. \& Dempsey, E. (2013). Healthy heroes, magic meals and a visiting alien: community-led assets-based social marketing. Social Marketing Quarterly, 19 (1), 2639. doi:10.1177/1524500412472493

Storbacka, K., Frow, P., Nenonen, S. \& Payne, A. (2012). Designing business models for value co-creation, in Stephen L. Vargo and Robert F. Lusch, (ed.) Special Issue - Toward a 
Better Understanding of the Role of Value in Markets and Marketing (Review of Marketing Research, 9, 51-78. doi: 10.1108/S1548-6435(2012)0000009007

Strauss, A. \& Corbin, J. (1994). Grounded theory methodology: An overview, in N. Denzin \& Y. Lincoln, (Eds.), Handbook of qualitative research, Thousand Oaks, CA: Sage, pp. 273285.

Truong. D. V. (2014). Social marketing: A systematic review of research 1998-2012. Social Marketing Quarterly, 20 (1), 15-34. doi:10.1177/1524500413517666

Vargo, S. L. \& Lusch, R. F. (2016). Institutions and axioms: an extension and update of service-dominant logic. Journal of the Academy of Science, 44, 5-23, doi 10.1007/s11747015-0456-3

Vargo, S. L. \& Lusch, R. F. (2014). Inversions of service-dominant logic. Marketing Theory, 14 (3), 239-248. doi:10.1177/1470593114534339

Vargo, S. L. \& Lusch, R. F. (2012). The nature and understanding of value: A ServiceDominant Logic perspective. Review of Marketing Research, 9, 1-12. doi: 10.1108/S15486435(2012)0000009005

Vargo, S. L \& Lusch, R. F. (2011) 'It's all B2B... and beyond: Toward a systems perspective of the market", Industrial Marketing Management, 40, 181-187. doi:10.1016/j.indmarman.2010.06.026

Vargo, S. L. (2011). Market systems, stakeholders and value propositions. European Journal of Marketing, 45 (1/2), 217-222. doi:10.1108/03090561111095667 
Vargo, S. L., Lusch, R. F., Archpru Akaka, M. \& He, Y. (2010). Service-dominant logic: A review and assessment. Review of Marketing Research, 6, 125-167. doi: 10.1108/S15486435(2009)0000006010

Vargo, S. L. \& Lusch, R. F. (2008). Service dominant logic: continuing the evolution. Journal of the Academy of Marketing Science, 36 (1), 1-10. doi:10.1007/s11747-007-0069-6

Vargo, S. L. \& Lusch, R. F. (2004). Evolving to a new dominant logic for marketing. Journal of Marketing, 68, 1-17. doi: 10.1509/jmkg.68.1.1.24036

Waller, A., Franklin, V., Pagliari, C. \& Greene, S. (2006). Participatory design of a text message scheduling system to support young people with diabetes. Health Informatics Journal, 12, 304-318. doi:10.1177/1460458206070023

White, H. C. (2008). Identity and control: How social formations emerge. Princeton: Princeton University Press.

Whitelaw, S., Smart, E., Kopela, J., Gibson, T. \& King, V. (2010). Developing social marketing capacity to address health issues. Health Education, 111 (4), 319-331. doi: $10.1108 / 09654281111144274$

Wilkinson, K. P. (1989). The future for community development, in J. A. Christenson \& J. W. Robinson Jr., (Eds.), Community Development in Perspective, Ames, Iowa: Iowa State University Press, pp. 337-354.

Winters, M. \& Patel, K. (2003). The Department of Health's Black and minority ethnic drug misuse needs assessment project. Centre for Ethnicity and Health, University of Central Lancashire and the Department of Health, London. 
Woodruff, R. B. \& Flint, D. J. (2006). Marketing's service-dominant logic and customer value, in R. F. Lusch \& S. L. Vargo, (Eds.), The service dominant logic of marketing: Dialog, debate and directions, Armonk, NY: M.E. Sharpe, pp. 183-195.

Zainuddin, N. (2013). Examining the impact of experience on value in social marketing. Journal of Social Marketing, 3 (3), 257-274. doi:10.1108/JSOCM-04-2013-0024

Zainuddin, N., Russell-Bennett, R. \& Previte, J. (2013). The value of health and wellbeing: an empirical model of value creation in social marketing. European Journal of Marketing, 47 (9), 1504-1524. doi: 10.1108/EJM-10-2011-0564

Zainuddin, N., Previte, J. \& Russell-Bennett, R. (2011). A social marketing approach to value creation in a well-women's health service. Journal of Marketing Management, 27 (3-4), 361385. doi:10.1080/0267257X.2011.547081

Zott, C., Amit, R. and Massa, L. (2011). The Business Model: Recent Developments and Future Research. Journal of Management, 37 (4), 1019-1042. doi:

$10.1177 / 0149206311406265$

Appendix: Table 1: Profiles of participants in semi-structured interviews

\begin{tabular}{|l|l|l|}
\hline $\begin{array}{l}\text { Participant name } \\
\text { (pseudonym) }\end{array}$ & Job role/position in the network & $\begin{array}{l}\text { Children's Centre/area } \\
\text { number }\end{array}$ \\
\hline Victoria & Manager & Centre 1 \\
\hline Bella & administrator/receptionist & Centre 1 \\
\hline Sella & family support officer & Centre 2 \\
\hline
\end{tabular}




\begin{tabular}{|c|c|c|}
\hline $\begin{array}{l}\text { Participant name } \\
\text { (pseudonym) }\end{array}$ & Job role/position in the network & $\begin{array}{l}\text { Children's Centre/area } \\
\text { number }\end{array}$ \\
\hline Sophie & Children's Centre teacher & Centre 2 \\
\hline Laura & manager & Centre 3 \\
\hline Kady & family support officer & Centre 3 \\
\hline Callie & manager & Centre 4 \\
\hline Christy & administrator/receptionist & Centre 4 \\
\hline Clarrise & childcare learning officer & Centre 4 \\
\hline Ellie & family support officer & Centre 4 \\
\hline Kelly & senior family support officer & Centre 4 \\
\hline Jessie & manager & Centre $5 \& 8$ \\
\hline Dana & play leader & Centre 5 \\
\hline Mira & manager & Centre 6 \\
\hline Penny & administrator/receptionist & Centre 6 \\
\hline Sylvia & manager & Centre 7 \\
\hline Karrie & administrator/ receptionist & Centre 7 \\
\hline Sandy & administrator/receptionist & Centre 8 \\
\hline Mona & manager & Centre 9 \\
\hline Jill & Childcare learning officer & Centre 9 \\
\hline Kathleen & manager Smokefree homes & \\
\hline Lydia & manager STOP & \\
\hline & & \\
\hline
\end{tabular}




\begin{tabular}{|c|c|c|}
\hline $\begin{array}{l}\text { Participant name } \\
\text { (pseudonym) }\end{array}$ & Job role/position in the network & $\begin{array}{l}\text { Children's Centre/area } \\
\text { number }\end{array}$ \\
\hline Maris & $\begin{array}{l}\text { clinical team leader for health visiting } \\
\text { and school nursing }\end{array}$ & centres $10 \& 11$ \\
\hline Lucy & health visitor team manager & centres $4,6 \& 8$ \\
\hline Sandra & health visitor & centre 8 \\
\hline Patty & health visitor & centre 8 \\
\hline Marcia & health visitor & centre 10 \\
\hline Alba & health visitor & centre 12 \\
\hline Shonda & health visitor & centre 11 \\
\hline Karla & $\begin{array}{l}\text { community health development } \\
\text { coordinator }\end{array}$ & centres $4 \& 8$ \\
\hline Minnie & $\begin{array}{l}\text { community health development } \\
\text { coordinator }\end{array}$ & centre 6 \\
\hline Sara & nurse & Children's Hospital \\
\hline Lara & training lead & Children's Hospital \\
\hline Paula & community midwife & area 13 \\
\hline Celina & maternity support worker & area 13 \\
\hline Claire & manager midwives team & area 13 \\
\hline Corrine & member of the public, smoker & centre 14 \\
\hline Gilbert & member of the public, ex-smoker & area 8 \\
\hline
\end{tabular}




\begin{tabular}{|l|l|l|}
\hline $\begin{array}{l}\text { Participant name } \\
\text { (pseudonym) }\end{array}$ & Job role/position in the network & $\begin{array}{l}\text { Children's Centre/area } \\
\text { number }\end{array}$ \\
\hline Jessica & member of the public, smoker & centre 7 \\
\hline Sal & $\begin{array}{l}\text { member of the public (Nadira's } \\
\text { spouse), ex-smoker }\end{array}$ & centre 5 \\
\hline Nadira & $\begin{array}{l}\text { member of the public (Sal's spouse), } \\
\text { non-smoker }\end{array}$ & centre 5 \\
\hline Selena & $\begin{array}{l}\text { member of the public, non-smoker (her } \\
\text { partner smokes) }\end{array}$ & area 15 \\
\hline Denisa & $\begin{array}{l}\text { member of the public, ex-smoker } \\
\text { partners smokes) }\end{array}$ & $\begin{array}{l}\text { area 5 } \\
\text { partner smokes) }\end{array}$ \\
\hline Kalista & $\begin{array}{l}\text { member of the public, non-smoker (her } \\
\text { partner smokes) }\end{array}$ & centre 5 \\
\hline Jenna & centre 5 \\
\hline Jarina & centre & centre 5 \\
\hline
\end{tabular}

